\title{
LARGE NECK TERATOMA IN A NEWBORN WITH RESPIRATORY DISTRESS SYNDROME
}

\author{
Orhideja Stomnaroska ${ }^{1}$, Goran Kocovski ${ }^{1}$, Panche Zdravkovski ${ }^{2}$,
} Boro Ilievski², Rubens Jovanovic ${ }^{2}$, Gordana Petrusevska ${ }^{2}$

\footnotetext{
${ }^{1}$ University Clinic for Gynaecology and Obstetritics, Medical Faculty, University Ss. Cyril and Methodius, Skopje, RN Macedonia

${ }^{2}$ Institute of Pathology, Medical Faculty, University Ss. Cyril and Methodius, Skopje, RN Macedonia
}

Corresponding author: Orhideja Stomnaroska, University Clinic for Gynaecology and Obstetritics, Medical Faculty Skopje, Vodnjanska BB, 1000 Skopje, Macedonia; stomnaroskao@yahoo.com

\begin{abstract}
Neonatal tumours in the neck region are a rare finding. Teratomas typically comprise all three germ cell layers with tissues usually foreign to the anatomic site of origin. Head and neck teratomas account a smaller part of congenital teratomas. They can cause major airway obstruction due to the external compression that oropharyngeal or neck masses produce. In addition, there can be an intrinsic lesion in the larynx or trachea. We describe a premature, 30-gestational week-old newborn with large subcutaneous neck mass. Pre-delivery ultrasound showed heterogeneous tumor structure and displaced larynx. The intubation was successful. The newborn developed respiratory distress syndrome immediately after birth which rendered the surgical removal of the neck tumor impossible. An autopsy was done, and the histopathology revealed mature teratoma comprising muscle, brain, salivary and pulmonary tissues, as well as well-developed hyaline membranes in the alveoli. The combination of the respiratory distress syndrome and the neck tumor compression proved fatal. Prenatal diagnosis, therapeutic options and ex utero intrapartum treatment (EXIT) procedures are discussed for the diagnosis and management of this very rare tumor.
\end{abstract}

Keywords: Newborn tumors, neck teratoma, neonatal cervical compression

\section{INTRODUCTION}

Teratomas are the most common type of germ cell tumours in childhood. The most common sites of occurrence in children are the sacrococcygeal region, gonads, mediastinum, and pineal region. Head and neck tumors comprise just $0.47 \%$ to $6 \%$ of all teratomas $[1,2]$. Their histology consists of the ectoderm, mesoderm, and endoderm. Neck teratomas have a propensi- ty towards airway obstruction. In addition, newborns can have intrinsic lesion in the larynx or trachea $[3,4,5]$. Cervical teratoma can be highly vascularized which can lead to lethal blood loss [6]. EXIT surgery is a preferred method to secure the fetal airway [3, 7-12]. We describe a newborn with a large subcutaneous neck tumor mass and hyaline membrane disease. 


\section{CASE REPORT}

This was the fourth delivery from a fifth pregnancy (one spontaneous abortion in the 3rd month of pregnancy) of a 30-year-old woman. The pregnancy was uneventful. There was no nicotine, alcohol or medications taken by the mother during the pregnancy. Several prenatal gynaecological and ultrasound examinations failed to discover the neck tumour. Alpha-fetoprotein was not prenatally analysed. Immediately before delivery, the ultrasound revealed a large neck mass measuring $7 \times 5 \times 5 \mathrm{~cm}$, which contained solid and cystic components (fig. 1). Polyhydramnios was evident. In the 30th week of pregnancy, the mother went into delivery and a cesarean headfirst delivery was performed. To secure the patency of the airway, direct laryngoscopy was performed for insertion of a breathing tube with positive pressure ventilation for severe respiratory distress, applied in the Neonatal Intensive Care Unit (NICU). This boy weighed 2,050 grams, with body length of $44 \mathrm{~cm}$. His Apgar scores were 4 at first minute, 5 at 5 minutes, and 6 at 10 minute.

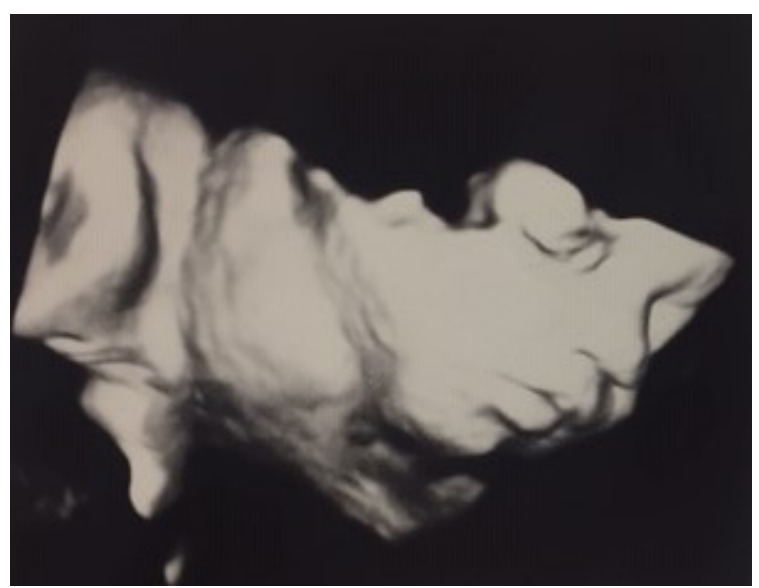

Fig. 1. Pre-delivery ultrasound of the neck with a large neck tumour

A large, cervical, subcutaneous tumour mass, predominantly left sided, but crossing to a large degree on right side was impressive (fig. 2 ). The tumor caused significant deformity of the neck, face and the airways. The dimensions were $7 \mathrm{~cm}$ by 5 anterior-posterior and superior-inferior. On palpation, it was tough and not tender, and there were no palpable lymph nodes. The skin was clean, and no openings, secretions or fistulas were noticeable. He required high levels of ventilator support and died at 18 hours of age.

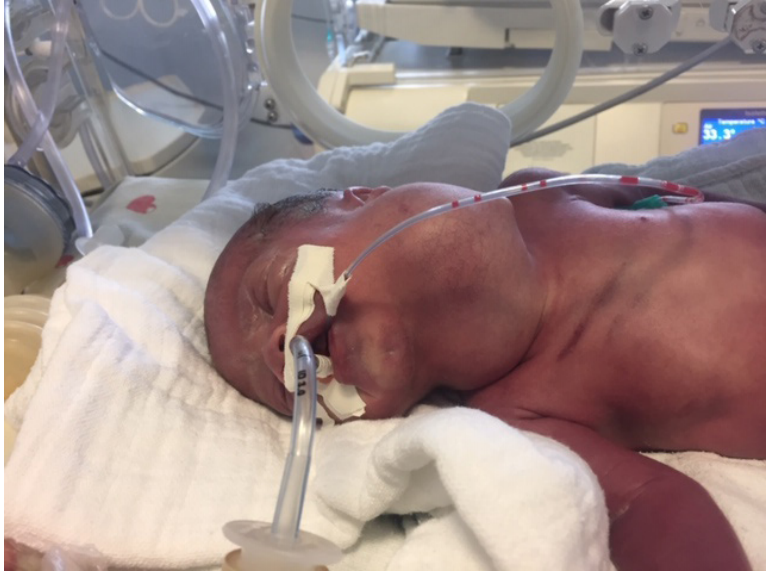

Fig. 2. Gigantic mass occupying the face and neck region with hyperextended head

The autopsy showed encapsulated friable tumour (fig. 3) with morphologic characteristic of mature teratoma with solid and cystic elements (fig. 4), histologically comprised of a mixture of mature chondroid tissue, brain tissue, respiratory cylindrical epithelium, ductal epithelium of salivary gland, striated muscle and squamous epithelium (fig. 5, 6,7). The cause of death was respiratory insufficiency because of respiratory distress with well-formed hyaline membranes, partial atelectasis and intra-alveolar hemorrhages.

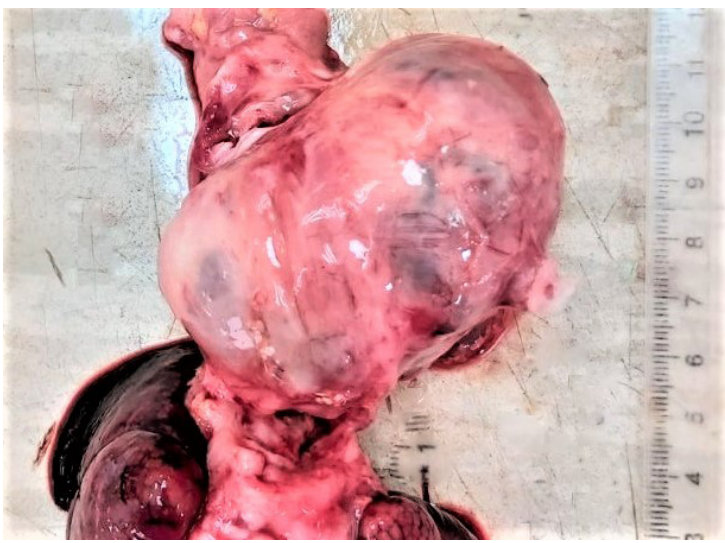

Fig. 3. Autopsy - Macrograph of the subcutaneous tumor mass in correlation with the airways.

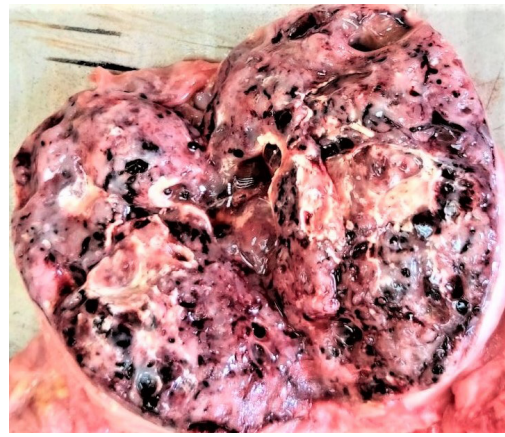

Fig. 4. Autopsy - Macroscopic cut-section revealed solid and cystic tumor appearance. 

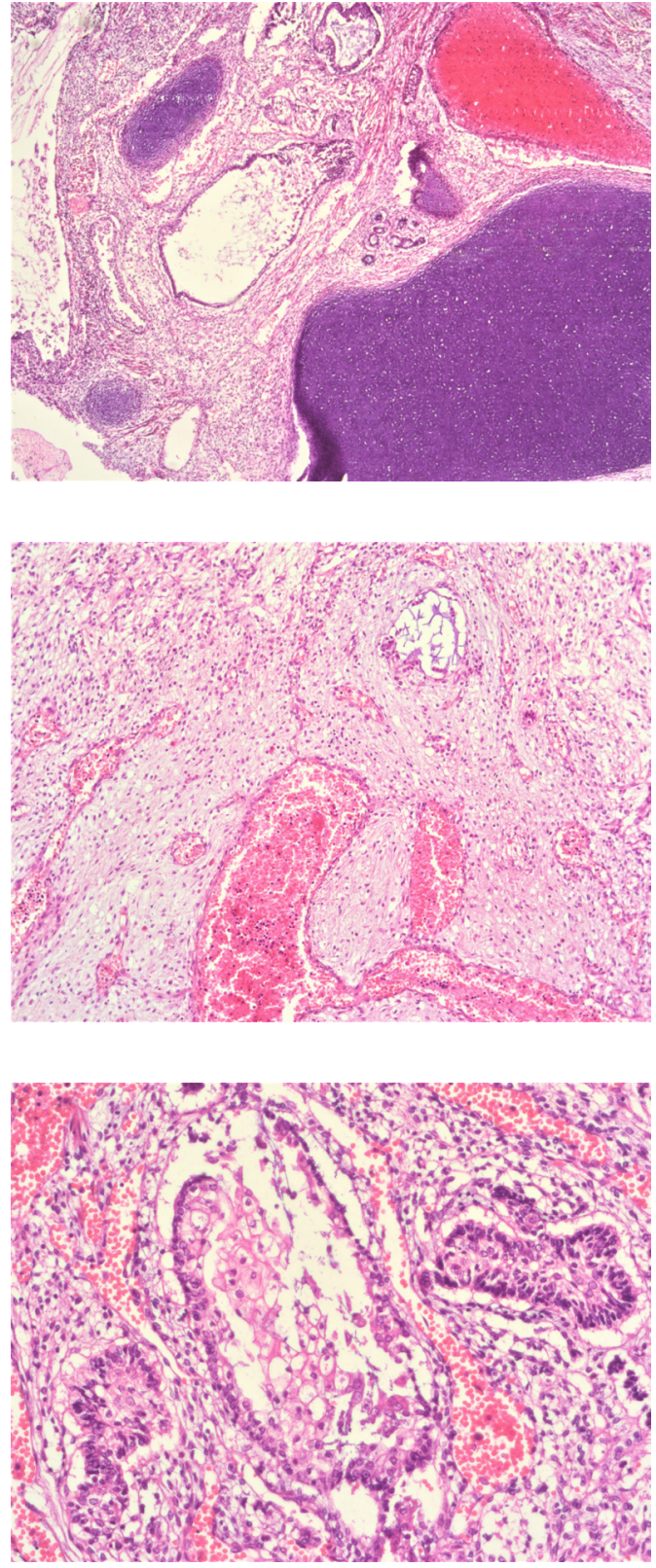

Fig. 5, 6, 7. Micrographs of mature teratoma comprised of mixture of mature chondroid tissue, brain tissue, respiratory cylindrical epithelium, ductal epithelium of salivary gland, striated muscle and squamous epithelium (Haematoxylin and Eosin stain; Magnification 5X, 10X and 20X)

\section{DISCUSSION}

Teratomas are rarely malignant. Nevertheless, they are associated with a high morbidity and mortality [3, 13]. Most teratomas appear in the sacrococcygeal region, whereas, teratomas in the neck region comprise $2 \%-9 \%$ of all congenital teratomas $[1,2]$. Neck teratomas are observed in approximately 1:20,000 to 1: 40,000 live births [1,
$2]$. The compression of the oropharyngeal structures from the tumour results in airway obstruction, which in foetus impair swallowing and produces polyhydramnios. The tumour can displace and pull the foetal lungs upward and can lead to severe lung hypoplasia. It is of note that the respiratory distress syndrome found in our patient was caused by hyaline membrane disease, and not by lung hypoplasia, and was the cause of death in this child.

Ultrasound or magnetic resonance imaging reveal solid or mixed cystic, with or without calcifications midline or anterolateral neck masses [8]. Differential diagnosis should include cystic hygroma/lymphangioma, goiter, hemangioma, neuroblastoma and sarcoma.

The EXIT procedure is a surgical procedure that allows the neonate to stay on placental support while the patency of the airway is secured [9-12]. Unfortunately, there wasn't a precise prenatal diagnosis, and the tumour was discovered by ultrasound only immediately before the mother went into spontaneous labour. Therefore, our patient did not have the chance to have an EXIT procedure. Nevertheless, the intubation was successful, mechanical ventilation was started and surfactant was administered. The chest X-ray showed ground glass appearance of the respiratory distress syndrome. Our patient did not develop coagulopathy, a common complication which can be caused by thrombosis in the tumour mass.

If a new-born survive an episode of respiratory distress syndrome, complications which can follow might be dysfunction of facial structures, neck musculature, and cranial nerves [13, 14].

The most important factor in neonatal survival is the correct and timely prenatal diagnosis. Unfortunately, the mother of the deceased neonate did not have the precise ultrasound or biochemical prenatal diagnosis. The pregnancy ultrasound examination failed to detect the neck tumour. Only the right prenatal diagnosis can make the delivery plan and potential treatment possible. The EXIT intervention is the only possible solution for a large cervical teratoma.

\section{REFERENCES}

1. Dunn CJ, Nguyen DL, Leonard JC. Ultrasound diagnosis of immature cervical teratoma: a case report. Am J Perinatol 1992; 9: 445-7.

2. Rothschild MA, Catalano P, Urken M, et al. Eval- 
uation and management of congenital cervical teratoma. Case report and review. Arch Otolaryngol Head Neck Surg 1994; 120: 444-8.

3. Tonni G, De Felice C, Centini G, et al. Cervical and oral teratoma in the fetus: a systematic review of etiology, pathology, diagnosis, treatment and prognosis. Arch Gynecol Obstet 2010; 282: 355-61.

4. Jordan RB, Gauderer MW. Cervical teratomas: an analysis. Literature review and proposed classification. J Pediatr Surg 1988; 23: 583-91.

5. Kerner B, Flaum E, Mathews H, et al. Cervical teratoma: prenatal diagnosis and long-term follow-up. Prenat Diagn 1998; 18: 51-9.

6. Olivares E, Castellow J, Khan J, Grasso S, Fong V. Massive fetal cervical teratoma managed with the ex utero intrapartum treatment (EXIT) procedure. Radiol Case Rep. 2018; 13(2): 389-391.

7. Wolter N.E., Siegele B., Cunningham M.J. Cystic cervical teratoma: a diagnostic and management challenge. Int J Pediatr Otorhinolaryngol. 2017; 95: 97-100.

8. Woodward P.J., Sohaey R., Kennedy A., Koeller K.K. From the archives of the AFIP: a comprehensive review of fetal tumors with pathologic correlation. Radiographics. 2005; 25(1): 215-242.
9. Thawani J.P., Randazzo M.J., Singh N., Pisapia J.M., Abdullah K.G., Storm P.B. Management of giant cervical teratoma with intracranial extension diagnosed in utero. J Neurol Surg Rep. 2016; 77(3): e118-e120.

10. Liechty K.W., Crombleholme T.M., Flake A.W., Morgan M.A., Kurth C.D., Hubbard A.M. Intrapartum airway management for giant fetal neck masses: the EXIT (ex utero intrapartum treatment) procedure. Am J Obstet Gynecol. 1997; 177(4): 870-874.

11. Peiro J.L., Sbragia L., Scorletti F., Lim F.Y., Shaaban A. Management of fetal teratomas. Pediatr Surg Int. 2016; 32(7): 635-647.

12. Sheikh F., Akinkuotu A., Olutoye O.O., Pimpalwar S., Cassady C.I., Fernandes C.J. Prenatally diagnosed neck masses: long-term outcomes and quality of life. J Pediatr Surg. 2015; 50(7): 1210-1213.

13. Brodsky J.R., Irace A.L., Didas A., Watters K., Estroff J.A., Barnewolt C.E. Teratoma of the neonatal head and neck: a 41-year experience. Int J Pediatr Otorhinolaryngol. 2017; 97: 66-71.

14. Potter's Pathology of the Fetus, Infant and Child, 2nd Edition, Volume 2, Part 4, Chapter 32, Germ cell tumors, Teratoma (2007).

\title{
Резиме
}

\section{ГОЛЕМ ТЕРАТОМ НА ВРАТ КАЈ НОВОРОДЕНЧЕ СО РЕСПИРАТОРЕН ДИСТРЕС СИНДРОМ}

\author{
Орхидеја Стомнароска ${ }^{1}$, Горан Коцовски ${ }^{1}$, Панче Здравковски ${ }^{2}$, \\ Боро Илиевски ${ }^{2}$ Рубенс Јовановиќ ${ }^{2}$, Гордана Петрушевска ${ }^{2}$ \\ ${ }^{1}$ Универзитетска клиника за гинекологија и акушерство, \\ Медицински факултет, Скопје, РС Македонија \\ ${ }^{2}$ Институт за патологија, Медицински факултет, Скопје, РС Македонија
}

Неонаталните тумори на вратот се исклучително ретки. Тератомите обично ги содржат сите три герминативни слоеви, како и ткива од други места во организмот. Тератомите на главата и вратот можат да предизвикаат опструкција на дишните патишта поради екстерна компресија од страна на нивната голема маса. Од друга страна, кај овие пациенти може да постои и додатна повреда на грлото и на душникот. Опишуваме новороденче што е родено во 30-тата гестациска недела со голема поткожна, хетерогена туморозна маса видена со ултразвук непосредно пред раѓање. Ларинксот беше потиснат, но интубацијата беше успешно изведена. Детето разви респираторен дистрес синдром што ја оневозможи хируршката екстирпација на туморот. Хистопатолошкиот наод покажа зрел тератом, во кој имаше и мускулно, мозочно, плунечно, белодробно ткаење. Во алвеолите се најдоа добро развиени хијалини мембрани. Комбинацијата на голем тератом на вратот и болеста на хијалини мембрани доведе до фатален исход. Во трудот е дискутирана пренаталната дијагноза, терапевтските можности и процедурата ex utero intrapartum treatment (EXIT).

Клучни зборови: неонатални тумори, тератом на вратот, неонатална компресија на врат 